\title{
Gas industry - a factor of international competitiveness
}

\author{
Sergey N. Lavrov ${ }^{\natural}$, Alexander G. Simonov ${ }^{2}$ \\ 1 “Western Petroleum Transportation” LLC, \\ 5A Skaterniy Ln, Moscow, 121069, Russian Federation \\ ${ }^{2}$ Peoples' Friendship University of Russia (RUDN University), \\ 6 Miklukho-Maklaya St, Moscow, 117198, Russian Federation \\ $\checkmark$ lavrovsn@mail.ru
}

\begin{abstract}
This is the first article of a series, devoted to a comprehensive problem of economic and geopolitical rivalry of the leading global powers in energy sector. It is dedicated to a number of topical issues of world economy and Russian economic environment. A systematic analysis of long-term world energy economy development trends is performed. For this purpose, a cause-and-effect relationship between international supply chains and energy procurement, on one hand, and revolutionary changes of international economic relations, caused by USA - China and Russia - USA, EU sanctions exchange, on the other, is derived. It is concluded that a developed gas industry is to play a decisive role in insuring global energy leadership of the major global powers on a mid- and long-term basis. A scenario analysis of further European gas market developments is provided. The external effects of developing gas industry are contemplated for Russian economic environment. In this framework most efficient options of action by Russian state are observed.
\end{abstract}

Keywords: gas industry, global competitiveness, economic leadership, international specialisation, green economy, energy security, sanctions, non-tariff regulation, supply chain, added value

Article history: received 13 November 2020; revised 30 November 2020; accepted 12 December 2020.

For citation: Lavrov, S.N., \& Simonov, A.G. (2021). Gas industry - a factor of international competitiveness. RUDN Journal of Economics, 29(1), 164-172. http://dx.doi.org/10.22363/ 2313-2329-2021-29-1-164-172

\section{Газовый сектор как фактор международной конкурентоспособности}

\author{
С.Н. Лавров ${ }^{1 凶}$, А.Г. Симонов ${ }^{2}$ \\ ${ }^{1} О О О$ «Вестерн Петролеум Транспортэйшн», \\ Российская Федераџия, 121069, Москва, Скатертный пер., д. 5 A \\ ${ }^{2}$ Российский университет дружбы народов, \\ Российская Федераџия, 117198, Москва, ул. Миклухо-Маклая, д. 6 \\ lavrovsn@mail.ru
}

Аннотация. Статья является первой из серии статей, посвященных проблеме комплексной экономической и геополитической конкуренции ведущих мировых держав в энергетическом секторе. Рассматриваются актуальные тенденции мировой экономики. 
Предпринята попытка системного анализа долгосрочных тенденций развития мировой энергетики на основе сравнения различных энергоносителей и сопоставления капитальных затрат сооружения электрогенерирующих мощностей на их основе. В этом контексте производится причинно-следственное сопоставление трансформации международных производственно-сбытовых цепочек и энергетического обеспечения экономики, с одной стороны, и революционных изменений международных экономических отношений, вызванных санкционным противостоянием по линиям США - Китай и Россия - ЕС, США, с другой. Делается вывод о первостепенном значении развитой газовой промышленности для повышения глобального энергетического лидерства мировых держав в среднеи долгосрочной перспективе. Представлен анализ дальнейшего развития европейского газового рынка, в рамках которого рассматриваются наиболее эффективные варианты действий российского государства.

Ключевые слова: газовая промышленность, глобальная конкурентоспособность, экономическое лидерство, зеленая энергетика, международная специализация, энергетическая безопасность, санкции, нетарифные ограничения, производственно-сбытовая цепочка, добавленная стоимость

История статьи: поступила в редакцию 13 ноября 2020 г.; проверена 30 ноября 2020 г.; принята к публикации 12 декабря 2020 г.

Для цитирования: Lavrov S.N., Simonov A.G. Gas industry - a factor of international competitiveness // Вестник Российского университета дружбы народов. Серия: Экономика. 2021. T. 29. № 1. C. 164-172. http://dx.doi.org/10.22363/2313-2329-2021-29-1-164-172

\section{Energy balances and trends}

Natural gas keeps expanding as a primary energy source for global energy procurement. Having only accompanied oil as a unique energy source for emerging automobile industry in the beginning of the $20^{\text {th }}$ century, it started to catch up rapidly in a post-war period (Figure 1).

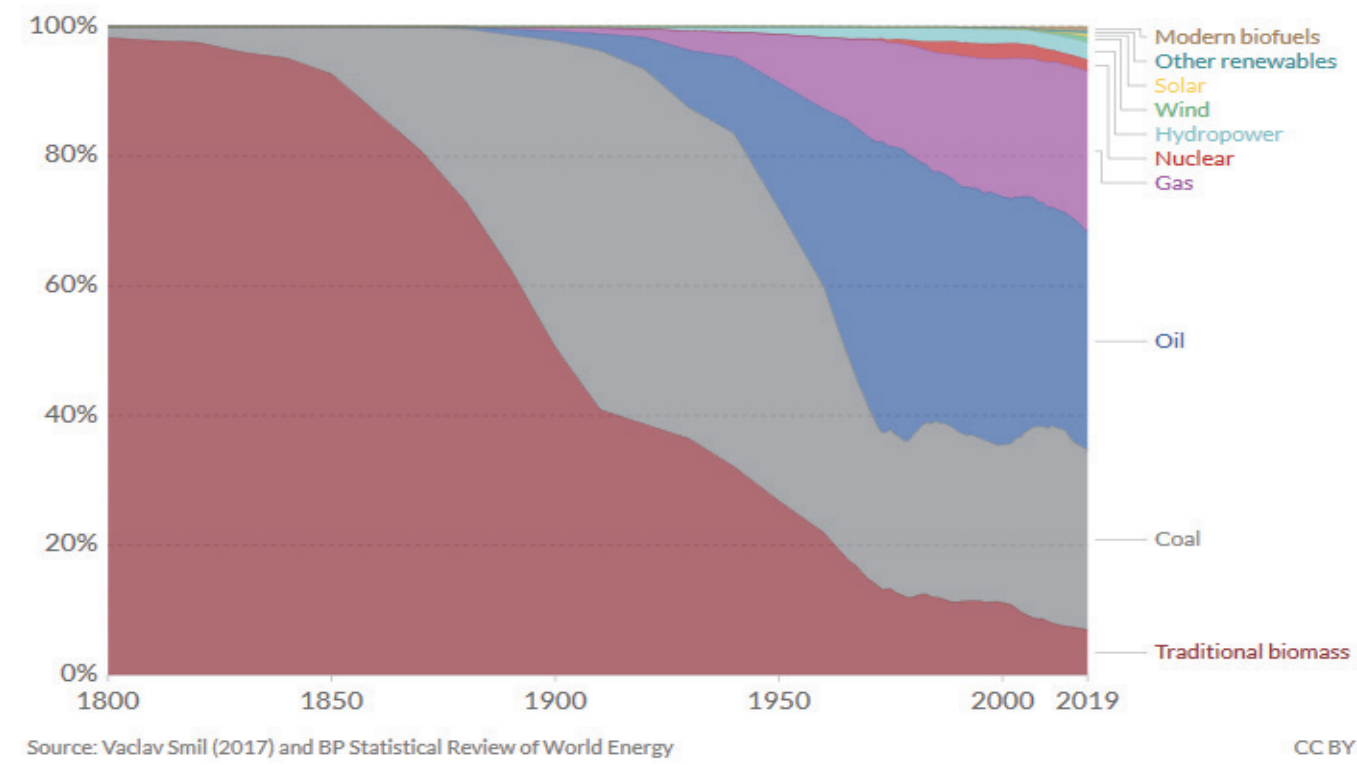

Figure 1. Global direct primary energy consumption

The rapid growth of the gas economic significance was stipulated by new materials and technologies providing for its extraction, treatment, and transporta- 
tion, which had been significantly obscured by lack of relevant technical means and systematic economic energetic interactions beforehand.

The development of utilization technologies and a well-established international transportation infrastructure gave way to natural gas as a promising global energy material, having several competitive advantages against all other fossil fuels: first, it has the highest specific calorific value (Tréanton, 2008), second methane (the main - up to $99 \%$ - component) being fully combusted produces only water and carbon dioxide without any hard particles and/or other carcinogenic substances (which is common for oil, coal, and biomass), moreover, the specific $\mathrm{CO}_{2}$ emission level is the lowest among all other hydrocarbons, and, third, natural gas, being lighter than air, escapes (or evaporates in case of LNG) rapidly, resulting in zero contamination of land and water in case of rupture and/or leakage.

Relatively high calorific value of natural gas in combination with energy carriers' price dynamic in recent years has resulted in the most competitive cost of energy production, ranging $\$ 44-73 / \mathrm{MWh}$ for new generation capacities and only $\$ 28 / \mathrm{MWh}$ for depreciated ones (Figure 2). The methodology applied was based upon market prices (Lazard, 2020) which means that gas producing entities, having vacant extraction capacities can achieve a stable cost leadership on international power market.

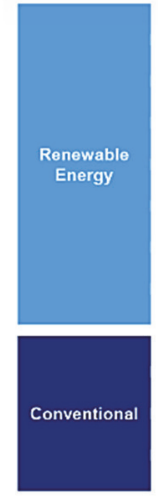

saurce: Lazard estinatea

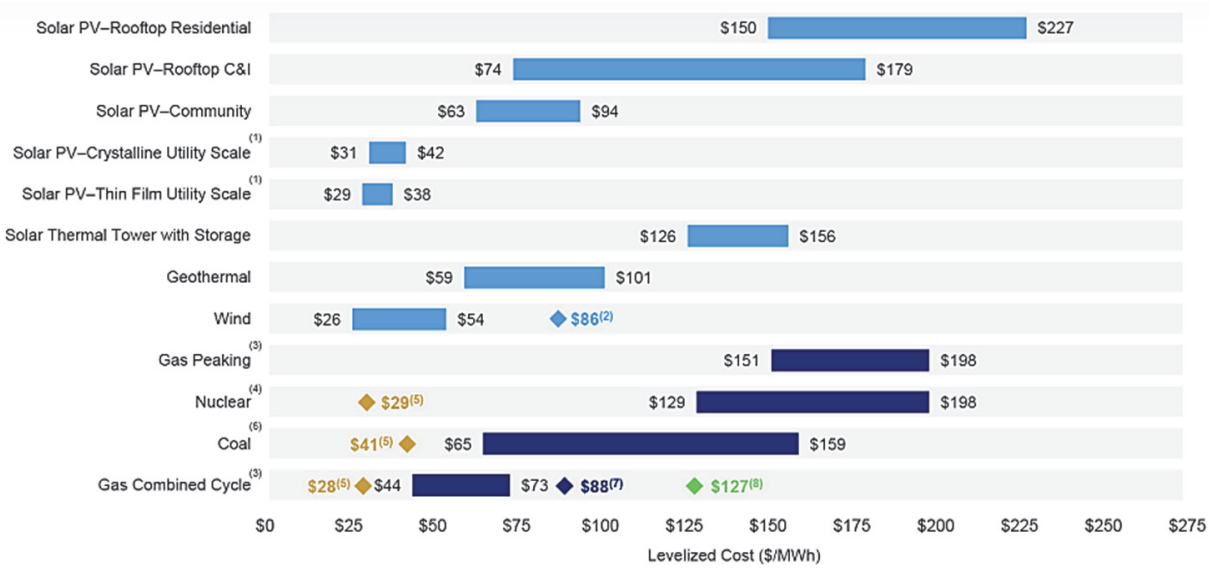

Figure 2. Cost efficiency of different generation technologies

Another reason to focus upon natural gas prospects are capital cost differences among a wide range of electricity generating technologies. According to calculations of U.S. Energy Information Administration report the overnight capital cost of CC-plants (fueled mainly by natural gas) commonly fall in-between $\$ 900-1,000$ per kilowatt; the relevant value for nuclear power usually exceeds $\$ 6,000$, coal $-\$ 3,000$, biomass $-\$ 4,000$, wind $-\$ 1,500$, and solar thermal $\$ 5,500$ (U.S. Energy Information Administration, 2020).

The factors spotted above can naturally explain gas having been demonstrating the most stable and vivid growth among all main energy carriers for the last three decades (Figure 3).

Moreover, natural gas is the only significant energy carrier, whose share has not deteriorated for this period (Figure 4). 


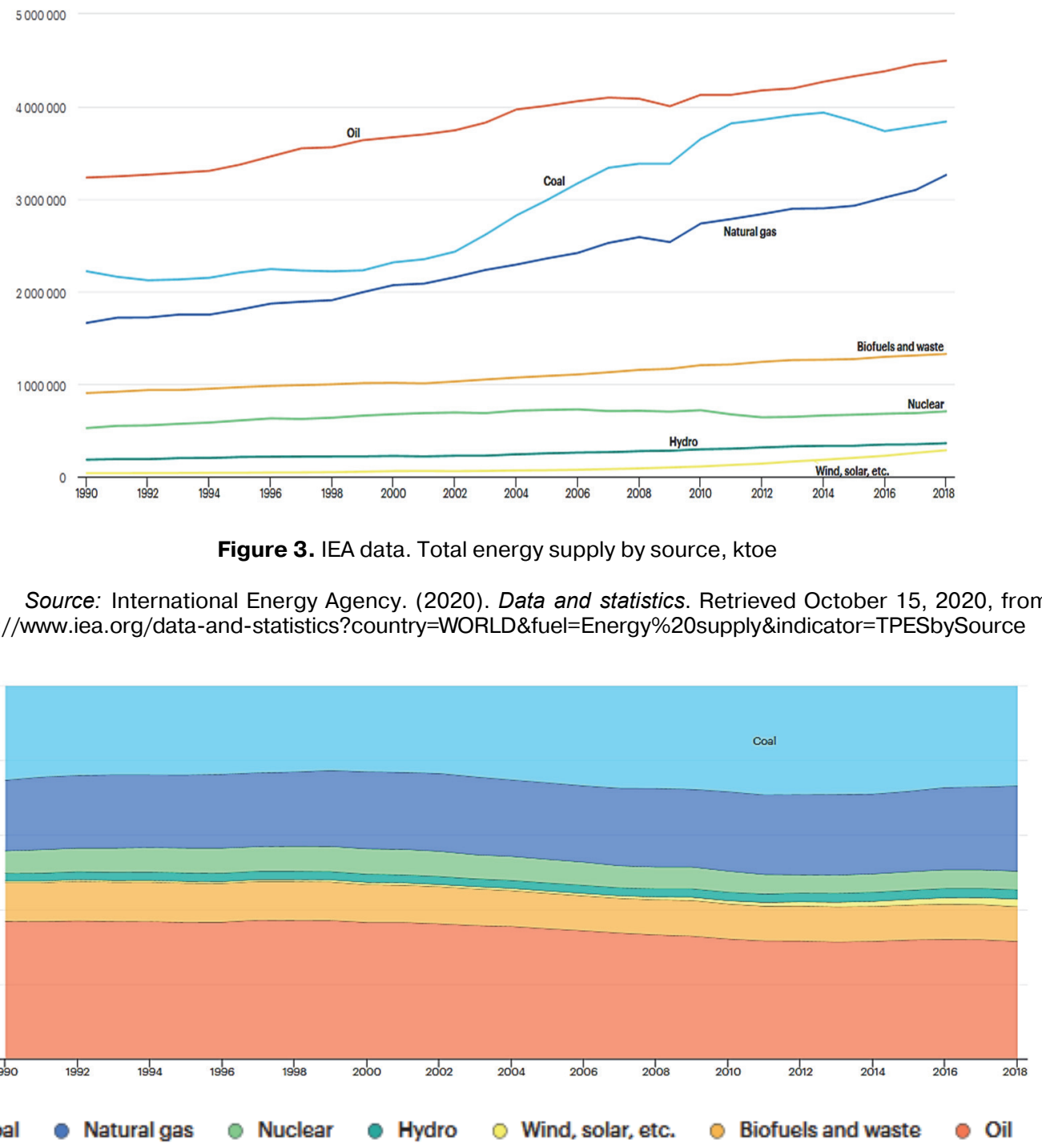

Figure 4. Shares of energy sources in traditional energy sources, $\%$

Source: International Energy Agency. (2020). Data and statistics. Retrieved October 15, 2020, from https://www.iea.org/data-and-statistics?country=WORLD\&fuel=Energy\%20supply\&indicator=TPESbySource

The further development of trends (a) for use of $\mathrm{LNG} / \mathrm{CNG}$ in transport, (b) for erecting new CC-plants capacities, and (c) for natural gas proliferation in residential sector may significantly shift stress upon NG as a main energy carrier in global economy. It shall also be noted, that fossil fuels hold above $80 \%$ of total energy supply and this share has not deteriorated for 30 years. However, there is a stable tendency for natural gas expansion within this fuel category. The future of renewables and alternative sources shall not be overestimated within short- and mid-term period. For instance, 20-20-20 goals, adopted by the EU, actually are hardly to be met without reliance upon natural gas as a key fossil energy source (Sánchez Nicolás, 2020).

The focus upon the EU (the largest and most developed market having shortage of domestic production), China, India (largest developing markets lacking own production and/or experiencing environmental issues caused by applying not environmentally compatible energy technologies), and Japan (a developed eco- 
nomy, due to geographical reasons, being among world top importers of energy materials) may provide a deep insight into the future of global energy market (especially its demand side).

\section{European energy arena}

International NG trade has been long performed mainly by pipelines, causing existence of relatively separate regional markets, emerged due to natural reasons. The development of LNG infrastructure in the beginning of $21^{\text {th }}$ century has caused merging of regional markets into a semi-global one. The main consequence of this process (or actually its reason) was shift of producers' focus on the most developed markets, exploiting high demand for NG imports, caused by lack of internal production and progressive energy mix development towards natural gas.

The consensus forecast (Komlev, 2016) published by Gazprom Export, world leading gas exporter, seems to have considerably underestimated the EU's gas deficit (Figure 5). The gap between indigenous production and imports has been growing more rapidly - according to the most recent data by IEA net imports exceeded domestic production by over 3 times (364 VS 94 Mtoe in 2018), while it was only 2,6 expected by supplying stakeholder.

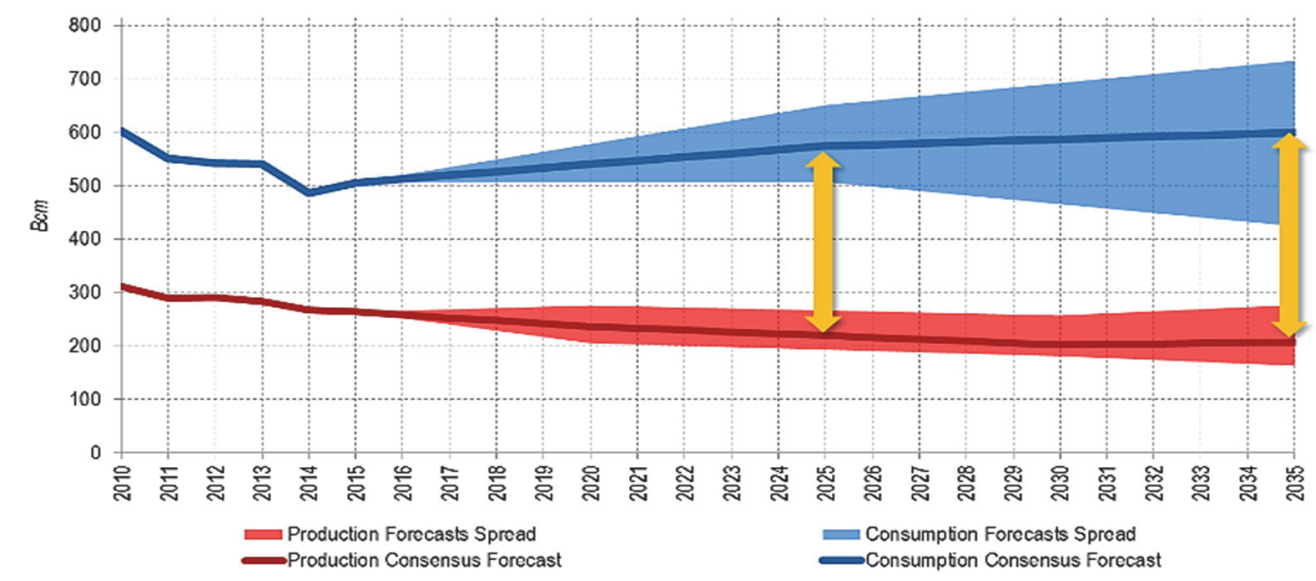

Figure 5. Gap between gas consumption and indigenous production in Europe

Source: Komlev S. (2016). Gazprom on European market: Challenges and solutions. ETCSEE2016 (15-16 June, Bucharest, Romania). Retrieved October 15, 2020, from http://www.gazpromexport.com/files/ 2016_06_10_ETCSEE_Komlev236.pdf

It is not surprising that European energy market attracts LNG producers from all over the world, who undertake a wide range of economic and political measures to receive additional profit margin. Nevertheless, increasing mobility of natural gas in combination with plunged oil prices (being a pricing factor for RussianEuropean long-term contracts with oil pegging) caused gas prices to go down too, leading to a significant threat of US producers' losses, as overall cost may exceed European prices for years (Figures 6 and 7). As it was computed by PIRA Russian exporter's costs are more than twice lower US ones (with tolling constituent), even in case of zero tolling fee Gazprom would have enjoyed 20\% cost leadership against only variable costs of US LNG suppliers. That may result in LNG insolvency in case of severe price competition (e.g. Bertrand competition model). 
Thus LNG suppliers can attempt to shift market interactions into an output-based competition (e.g. Cournot model) which would have been hardly effective due to sufficient spare extraction capacities of Russian producers. So there is another option for LNG suppliers, which is undermining and/or restricting infrastructure links between the EU and Russia. Political sanctions against Nord Stream 2 project may be a vivid example.

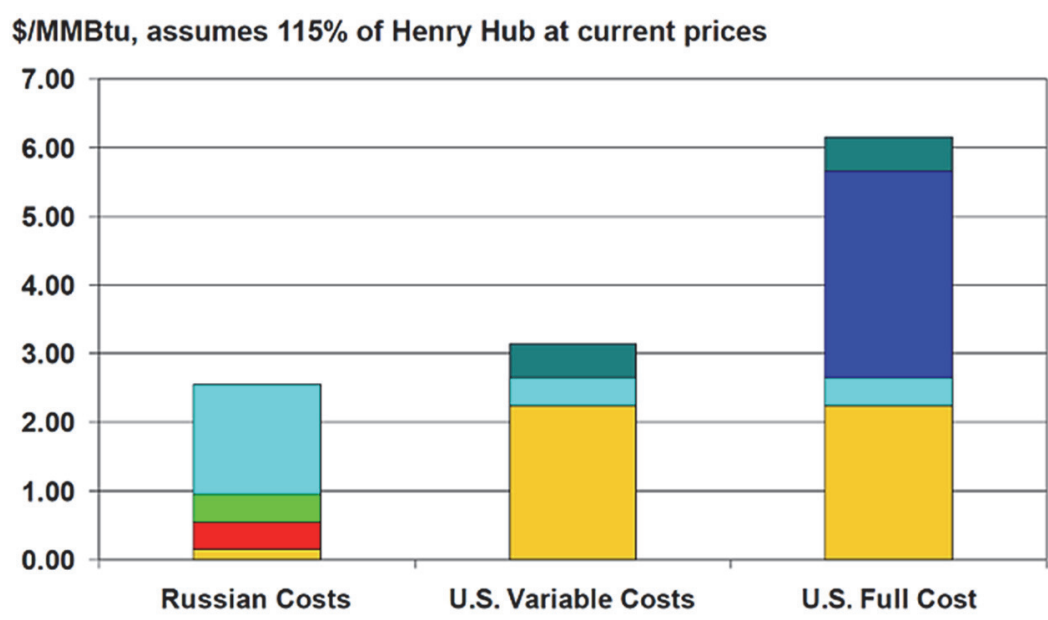

$\square$ Lifting Cost/Commodity Charge $\square$ Maintenance/Capex $\square$ Taxes $\square$ Transportation Costs $\square$ Tolling $\square$ Regas

Source: PIRA

Figure 6. Costs comparison of Russian NG and U.S. LNG

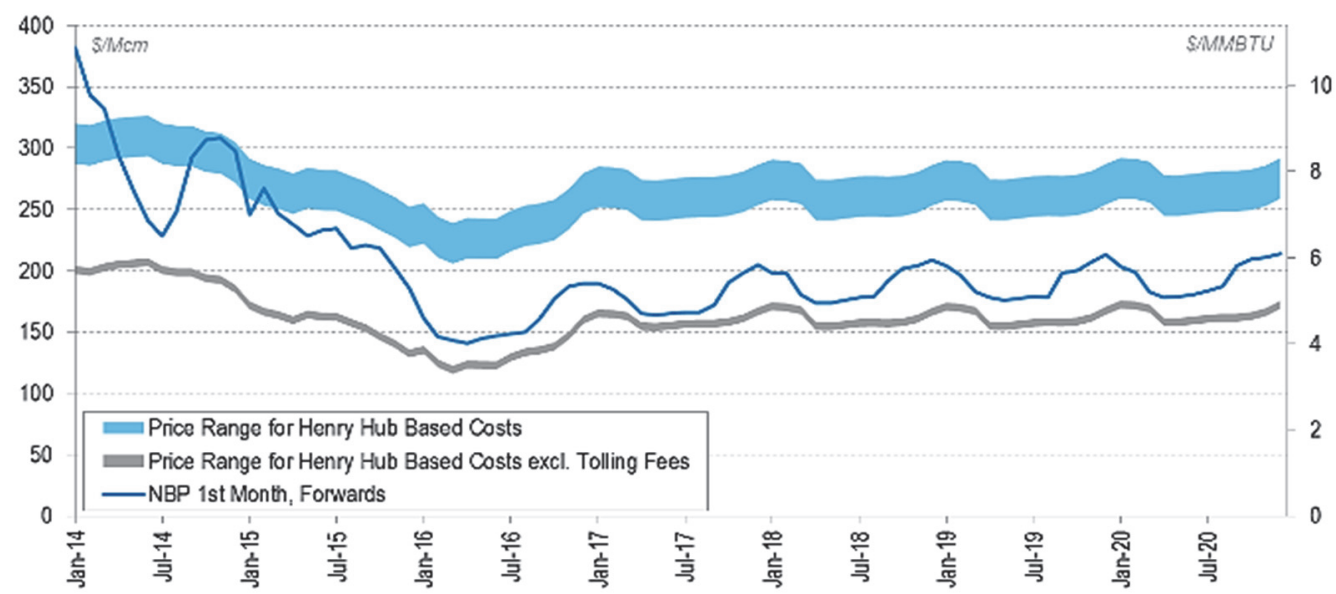

* Based on Henry Hub Forward Curve, $P=H H * 115 \%+X$, where $X$ - costs of liquefaction, shipping, regasification

* NBP Forward Curve

Source: Bloomberg, Wood McKenzie

Figure 7. Estimated costs of U.S. LNG deliveries to Europe in comparison with European traded forwards

After traditional methods of business competition are exhausted, state interference in a form of geopolitical actions can follow. The scale and scope of such interference in international business activity may vary from considerable to overwhelming (e.g. Third Energy Package by the EU, or unprecedented attempted banning of TikTok in USA, or U.S. sanctions against Nord Stream 2). The weight of efforts witnesses two facts. First, energy (gas) industry exports and relevant 
jobs being created are undoubtedly worth state resources engaged. Second, global economy has indivisibly merged with global politics, resulting in new reality for entities operating internationally. Moreover, traditional integration blocs and units are not treated equally and consistently: different members receive unequal approach from U.S. government and economic agents (Konovalova, Ushanov, 2019). As a result, we are on the edge of new global economic order with states and enterprises being participants of economic relations without hardly any political or legal restriction on competitive tools.

\section{Gas industry as a factor of global competitiveness}

As for now gas industry provides several prominent competitive advantages for the countries developing it. In terms of Russian social and economic system the following are most relevant.

Jobs creation. Gas industry development provides for a massive creation of new jobs (new fields, new infrastructure, new plants and stations, increasing demand for new equipment, machines and materials). These jobs have several prominent advantages, securing sustainable growth and development. First, the jobs are created on a long-term basis (the need for infrastructure operation and maintenance are not susceptible to economic fluctuations). Second, these jobs require high-qualified staff, which stimulates educational progress and income increase (gas industry is among top-paid industries with highest wages in Russia and in the world). Third, a great part of jobs in gas sector do not gravitate to center, which may be a partial solution of a traditional Russian problem - asymmetric development of large cities and income distribution.

Basic resources provision (energy + prospective chemical input). In terms of sustainable economic development and basic inputs provision gas industry is a promising candidate. Unlike crude oil natural gas is a rather homogeneous product with the highest calorific value. Moreover, it has potential for improvement its green qualities (for instance, carbon capture and sequestration). There are also a number of technologies of NG chemical appliance, being actively developed (Al-Mohannadi et al., 2018).

Enhancing exports potential. The analysis above allows expecting further growth of world trade in natural gas (both in gaseous form in regional markets and in a form of LNG for global trade operations). The emerging of an integral global gas market, caused by relevant midstream infrastructure development, may significantly increase international competitiveness of countries, having established NG export potential. It is essential both in terms of macroeconomic stability (current account balance) and domestic growth and development.

Insuring cost leadership. A developed gas sector infrastructure accompanied by well-explored reserves may provide a solid ground for primary and secondary sectors. The starting energy transition in fossil fuels shifts a key role in energy security to NG as a primary fuel in industry, residential, and even transport sectors (Konoplyanik, 2019). Many supply chains start in gas industry. Natural gas, accountable in Russia for $56 \%$ of total energy supply and $48 \%$ of electricity power generation, can become a basis for cost leadership of many Russian companies, including agriculture, chemical, manufacturing, transport, and power generating ones. 


\section{Russian gas industry and state policy}

According to several research studies the domestic gas market of Russia is saturated and enjoys excessive gas supply from independent gas producers, causing prices to stay relatively low (Andronova, Kolbikova, 2016). Meanwhile a developing energy transition and fuel shift in industrial, residential, and transport sectors are highly likely to cause a long-term increasing demand for NG worldwide. In this respect it is crucial to elaborate a state policy towards domestic gas industry in order to find and keep comprehensive balance between overall economic development and global positions of Russia's energy companies.

Another discussion point is global gas maker interaction model. The situation may come close to that on the oil one with Russia and OPEC rivalry, causing prices to fall into negative territory. However, it is important to stress, that crisis resolution was fostered afterwards by USA as well (Reed, 2020). The latter witnesses USA preferable positioning as energy producer rather than consumer (at least in terms of external effects, provided by this industry). This bring us to a perception of global energy economy as a hard trade-off between national leadership, profit maximization on one side and risk of overall decline as well as negative spillovers on the other.

The idea of Marina Larionova (2016), that "contested multilateralism has a positive dimension, as the emergence of informal multilateral institutions claiming a major role in defining the global governance agenda creates alternatives for providing common goods" may be now applied to a global energy market as well. The de facto fiasco of several global institutions (like WTO, Energy Charter, etc.), regulating international economic relations, opens the floodgates to a new economic order, with states and companies interacting in a free market with no restrictions regarding both geopolitical as well as economic collusions and standoffs.

\section{References}

Al-Mohannadi, D.M., et al. (2017, December). On the synthesis of carbon constrained natural gas monetization networks. Journal of Cleaner Production, 168, 735-745. doi: 10.1016/ j.jclepro.2017.09.012.

Andronova, I.V., \& Kolbikova, E.S. (2016). Russian natural gas reforms and trends on the domestic and export markets. RUDN Journal of Economics, (4), 31-38.

Carr, M. (2019, August 8). U.S. sanction plan for Russian pipe could repeat Reagan failures. Bloomberg. Retrieved November 15, 2020, from www.bloomberg.com/news/articles/ 2019-08-08/u-s-sanction-plan-for-russian-pipe-could-repeat-reagan-failures

Komlev S. (2016). Gazprom on European market: Challenges and solutions. ETCSEE2016 (15-16 June, Bucharest, Romania). Retrieved October 15, 2020, from http://www.gazpromexport.com/files/2016_06_10_ETCSEE_Komlev236.pdf

Konoplyanik, A.A. (2019). O novoj paradigme razvitiya mirovoj energetiki, riskah i vyzovah dlya Rossii i mira [About the new paradigm of development of global energy, risks and challenges for Russia and the world]. Moscow, The Institute of Economic Forecasting of the Russian Academy of Sciences.

Konovalova, Yu.A., \& Ushanov, S.A. (2019). EU in the system of trade interests of USA. RUDN Journal of Economics, 27(2), 386-400. http://dx.doi.org/10.22363/2313-23292019-27-2-386-400

Larionova, M.V. (2016). Evaluating global institutions' effectiveness. International Organisations Research Journal, 11(1), 126-152. 
Lazard. (2020). Levelized cost of energy and levelized cost of storage - 2020. Retrieved October 15, 2020, from www.lazard.com/perspective/levelized-cost-of-energy-andlevelized-cost-of-storage-2020/

Reed, S. 6 June 2020. OPEC and Russia agree to extend oil production cuts. The New York Times. Retrieved October 15, 2020, from www.nytimes.com/2020/06/06/business/energyenvironment/opec-russia-oil-coronavirus.html

Sánchez Nicolás, E. Why is EU off track for 2020 energy efficiency target? EUobserver. Retrieved October 15, 2020, from euobserver.com/energy/147407

Streimikiene, D., et al. (2020, June 1). Climate change mitigation in households between market failures and psychological barriers. Energies, 13(11), 2797. doi: 10.3390/en13112797.

Tréanton, K. (2008). International workshop on energy statistics units of measurement and conversion, prices and emissions section. UN Statistical Department. Retrieved October 15, 2020, from https://unstats.un.org/unsd/energy/meetings/mexico2008/Presentations/Session $\% 206 \% 20-\% 20$ Introduction.pdf

U.S. Energy Information Administration. (2020). Cost and performance characteristics of new generating technologies. Annual Energy Outlook 2019. Retrieved October 15, 2020, from https://www.eia.gov/outlooks/aeo/assumptions/pdf/table_8.2.pdf

U.S. Energy Information Administration. (2020). Cost and performance characteristics of new generating technologies: Annual energy outlook 2019. Retrieved October 15, 2020, from https://www.eia.gov/outlooks/aeo/assumptions/pdf/table_8.2.pdf

\section{Сведения об авторах / Bio notes}

Лавров Сергей Николаевич, доктор экономических наук, профессор, советник-консультант ООО «Вестерн Петролеум Транспортэйшн». E-mail: lavrovsn@mail.ru.

Симонов Александр Геннадьевич, кандидат экономических наук, доцент кафедры международных экономических отношений Российского университета дружбы народов. E-mail: simonov-ag@rudn.ru.
Sergey N. Lavrov, Doctor of Sciences (in Economics), Professor, advisor-consultant of the "Western Petroleum Transportation" LLC. E-mail: lavrovsn@mail.ru.

Alexander G. Simonov, PhD (in Economics), Associate Professor of the Department of International Economic Relations of the Peoples' Friendship University of Russia (RUDN University). E-mail: simonov-ag@rudn.ru. 